\title{
Jacques de Voragine, La Légende dorée
}

\section{G. Matteo Roccati}

\section{(2) OpenEdition}

\section{Journals}

\section{Édition électronique}

URL : http://journals.openedition.org/studifrancesi/34288

DOI : 10.4000/studifrancesi.34288

ISSN : 2427-5856

\section{Éditeur}

Rosenberg \& Sellier

\section{Édition imprimée}

Date de publication : 1 novembre 2005

Pagination : 389

ISSN : 0039-2944

\section{Référence électronique}

G. Matteo Roccati, « Jacques de Voragine, La Légende dorée », Studi Francesi [En ligne], 146 (XLIX | II) | 2005, mis en ligne le 30 novembre 2015, consulté le 19 avril 2021. URL : http://

journals.openedition.org/studifrancesi/34288; DOI : https://doi.org/10.4000/studifrancesi.34288

\section{Ce document a été généré automatiquement le 19 avril 2021.}

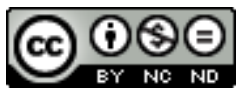

Studi Francesi è distribuita con Licenza Creative Commons Attribuzione - Non commerciale - Non opere derivate 4.0 Internazionale. 


\title{
Jacques de Voragine, La Légende dorée
}

\author{
G. Matteo Roccati
}

\section{RÉFÉRENCE}

JACQUES DE VORAGINE, La Légende dorée, préface de Jacques LE GOFF, édition publiée sous la direction d'Alain BOUREAU, avec Monique GOULLET et la collaboration de Pascal ColLOMB, Laurence MOULINIER et Stefano MULA. «La Légende dorée et ses images» par Dominique Donadieu-Rigaut, Paris, Éditions Gallimard («Bibliothèque de la Pléiade»), 2004, pp.

CXII-1550.

$1 \quad$ L'Introduction (pp. XV-XLVIII), offre une synthèse éclairante sur l'œuvre, le travail et les motivations de Jacques de Voragine; elle est suivie d'une Note sur la présente édition, qui fait le point sur les éditions et traductions existantes, d'une chronologie et d'une étude sur les illustrations de la Légende dorée (pp. LVII-CXI).

2 La traduction a été établie sur l'édition de G.P. Maggioni (Florence, 1998 et 1999). Elle est accompagnée d'un riche apparat de Notes (pp. 1059-1489): outre les annotations au texte, on trouvera pour chaque chapitre de l'ouvrage (temps liturgiques et saints) une notule introductive, avec bibliographie spécifique. Terminent le volume la bibliographie générale (pp. 1493-1494), l'Index des noms de personnes et de lieux (pp. 1497-1517), l'Index thématique (pp. 1519-1526), la liste des sources (pp. 1527-1540) et la Table alphabétique des saints.

Excellent instrument de travail. 